\title{
Peroxynitrite Inactivates Carbonic Anhydrase II by Releasing Active Site Zinc Ion
}

\author{
Young-Mi Kim and Sanghwa Han ${ }^{*}$ \\ Department of Biochemistry, Kangmon Vational Lniversitv, Chunchon 200-701, Korea \\ Received Harch 29, 2004
}

\begin{abstract}
Peroxynitrite enters erythrocytes through band 3 anion exchanger and oxidizes cytosolic proteins therein. As a protein associated with band 3. carbonic anhydrase II may suffer from peroxynitrite-induced oxidative damages. Esterase activity of carbonic anlydrase II decreased as the concentration of peroxynitrite increased. Neither hydrogen peroxide nor hypochlorite affected the enzyme activity. Inactivation of the enzyme was in parallel with the release of zinc ion, which is a component of the enzyme's active site. SDS-PAGE of peroxy nitrite-treated samples showed no indication of fragmentation but non-denaturing PAGE exhibited new bands with lower positive charges. Westem analysis demonstrated that nitration of tyrosine residues increased with the peroxy nitrite concentration but the sites of nitration could not be deternined. Instead MALDI-TOF analysis identified tryptophan- 245 as a site of nitration. Such modification of tryptoplan residues is responsible for the decrease in tryptophan fluorescence. These results demonstrate that peroxy nitrite nitrates tyrosine and tryptophan residues of carbonic anhydrase II without causing fragmentation or dimerization. The peroxynitriteinduced inactivation of the enzy me is primarily due to the release of zinc ion in the enzyme's active site.
\end{abstract}

Key Words : Carbonic anhỵdrase. Peroxỵnitrite. Inactivation. Zinc

\section{Introduction}

Blood can encounter various reactive oxygen and nitrogen species. Vascular and innume cells produce nitric oxide. superoxide. hydrogen peroxide. and hypochlorite. Nitric oxide and superoxide react very rapidly $\left(\mathrm{k} \sim 10^{1 \mathrm{j}} \mathrm{M}^{-1} \mathrm{~s}^{-1}\right)$ to produce peroxynitrite. a strong oxidant that oxidizes and nitrates biological molecules. ${ }^{1}$ Endotoxin-induced generation of peroxynitrite has been demonstrated in blood plasna. ${ }^{2}$

Once formed in plasma, peroxynitrite can cross the erythrocyte membrane in the anionic form through band 3 anion exchanger and in the protonated form by passive diffusion. $^{3}$ In the cytosol of erythrocytes, perosynitrite oxidizes hemoglobin, ${ }^{4}$ modulates tyrosine-dependent signal transduction. ${ }^{56}$ and depletes glutathione. ${ }^{7}$ Hydrogen peroxide can also diffuse into ery throcy tes and oxidize hemoglobin. ${ }^{8,9}$ Hypochlorite causes damage to the erythrocyte menbrane and membrane proteins ${ }^{11}$ but the danage to cytosolic components has not been characterized.

Carbonic anthydrase is found in almost all organisms and involved in diverse biological processes including photosynthesis. the formation of ocular fluid, and the $\mathrm{CO}_{2}$ exchange between the blood and tissues. ${ }^{11}$ The enzyme catalyzes the reversible hydration of carbon dioxide: $\mathrm{CO}_{2}+$ $\mathrm{H}_{2} \mathrm{O}=\mathrm{H}^{-}+\mathrm{HCO}_{3}{ }^{-}$. Human carbonic anlyydrase II (CA II) is an extremely efficient enzyme with $\mathrm{k}_{\mathrm{cat}^{-}} 10^{6} \mathrm{~s}^{-1}$. The enzyme contains a $\mathrm{Zn}^{\hat{2}^{-}}$ion in its active site which is coordinated by three histidine ligands. CA II binds to band $3^{12}$ and ion channels $^{13}$ and modulates their functions. Since band 3 serves as the entrance channel for perosynitrite, it is worth analyzing the interaction of CA II with peroxynitrite.

Correspondence should be addressed. Tel: $+82-33-250-8516$; Fax: +82-33-242-0459: e-mail: hansh atkangwon.ackst
In this study, we demonstrated that peroxynitrite inactivates human CA II by releasing zinc ion from the active site The protein moiety of the enzyme was also damaged by perosynitrite.

\section{Experimental Section}

Materials. Human carbonic anhydrase II was purchased from Signa (St. Louis, MO. USA). Antinitrotyrosine antibody was from Upstate Biotechnology (Lake Placid. NY, USA) and ECL Western blotting detection reagents were from Amhersham (Buckinghamshire. UK). FluoZin-3. a $\mathrm{Zn}^{2-}$ probe. was obtained from Molecular Probes (Eugene. OR. USA) All other chemicals were from Sigma. Perosynitrite was prepared by the reaction of $\mathrm{H}_{2} \mathrm{O}_{2}$ and isoamyl nitrite. ${ }^{14}$ Concentration of peroxynitrite was measured spectrophotometrically by using $\varepsilon=1670 \mathrm{M}^{-1} \mathrm{~cm}^{-1}$. Buffer $(0.1 \mathrm{M}$ Tris $\mathrm{HCl}$, $\mathrm{pH} 7.4$ ) was treated with Chelex- 100 to remove trace metal ions.

Enzyme activity measurements. Human CA II (10 $\mu \mathrm{M})$ was treated with perosynitrite of a given concentration and incubated at $35^{\circ} \mathrm{C}$ for $30 \mathrm{~min}$. An aliquot $(100 \mu \mathrm{L})$ of the perosynitrite-treated enzyme was added to $1.9 \mathrm{~mL}$ Tris buffer and $0.9 \mathrm{~mL} p$-nitrophenylacetate. Increase in the absorption at $348 \mathrm{~nm}$ was monitored by using a HewlettPackard HP 8483 spectrophotometer (Palo Alto, CA. USA).

Quantitation of released zinc ion. FluoZin-3, upon binding $\mathrm{Zn}^{2+}$. fluoresces at $516 \mathrm{~mm}$ when excited at $494 \mathrm{~mm}$ The peroxynitrite-treated samples were diluted to a funal enzyme concentration of $1 \mu \mathrm{M}$. FluoZin-3 (2 $\mu \mathrm{M})$ was added and the fluorescence spectrum was obtained by using SLM-Aninco AB-2 luminometer (Urbana-Champaign. Il, USA).

Westem blotting. Samples were subjected to $10 \%$ SDS- 
PAGE and the protein bands were transferred to nitrocellulose membrane. Western blotting was performed by using antinitrotyrosine antibody and $\mathrm{CCl}$. Westem blotting detection reagents.

MALDI-TOF mass spectrometry. The peroxynitritetreated samples were hydrolyzed by adding trypsin. MAI.DITOF spectra were obtained on a Applied Biosystems Voyager-DГ: STR spectrometer (Foster City, CA. USA). Fxperimentally obtained peptide masses were entered into the ProteinProspector program for comparison to the known sequence of human CA II.

\section{Results}

Vascular and immune cells produce various ROS/RNS that can attack erythrocytes. The primary ROS/RNS include superoxide and nitric oxide, from which $\mathrm{H}_{2} \mathrm{O}_{2}$ and peroxynitrite are formed. In addition, neutrophil produces $\mathrm{HOCl}$ which is involved in killing of invading pathogens. Therefore $\mathrm{H}_{2} \mathrm{O}_{2}, \mathrm{HOCl}$, and peroxynitrite are three major species in the blood that may affect the activity of carbonic anhydrase 11 in erythrocytes.

We incubated human CA II in $1 \mathrm{mM}$ each of these oxidants and measured the esterase activity of the enzyme. As shown in Figure $1, \mathrm{H}_{2} \mathrm{O}_{2}$ did not alter the activity of CA II whereas $\mathrm{HOCl}$ reproducibly enhanced the activity by $\sim-30 \%$. S-nitrosothiols, which donate nitric oxide, did not affect the enzyme activity (not shown). Peroxynitrite was the only oxidant that inactivated CA ll by $-50 \%$.

We next measured the concentration dependence of the inactivation. Figure 2 shows that the activity of CA II (filled circles) decreased as the peroxynitrite concentration increased. About $30 \%$ of the activity was lost when the enzyme was incubated with $200 \mu \mathrm{M}$ peroxynitrite, which is in 20 -fold excess of the enzyme.

CAll contains a zine ion in the active site that participates

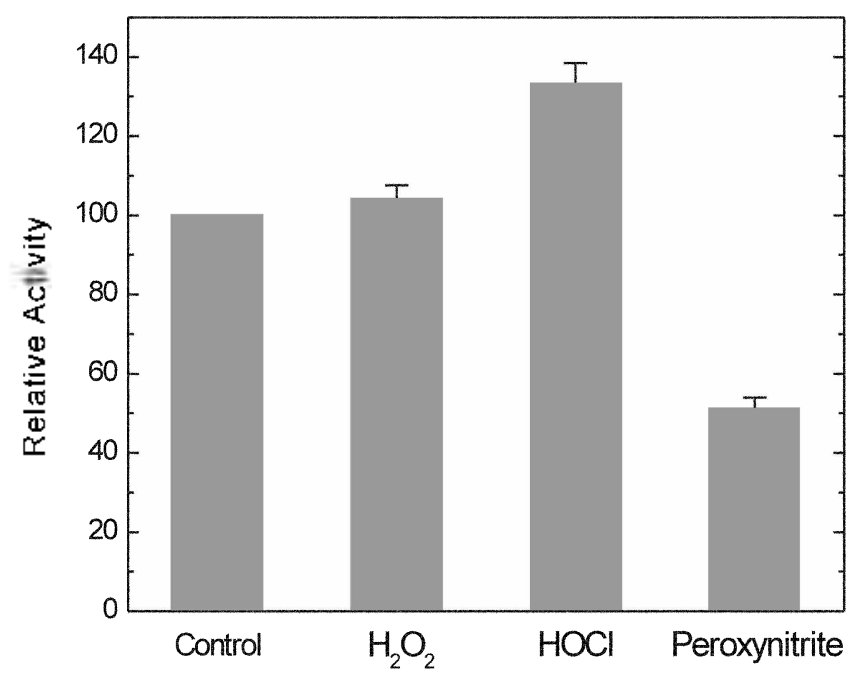

Figure 1. Fiffects of oxidants on the activity of carbonic anhydrase II. CA Il $(10, \mu \mathrm{M})$ was incubaled with $1 \mathrm{~m} . \mathrm{M}$ each of the oxidants al $35^{\circ} \mathrm{C}$ for $30 \mathrm{~min}$. The enzyme's esterase activity was measured by the method described in Experimental Section.

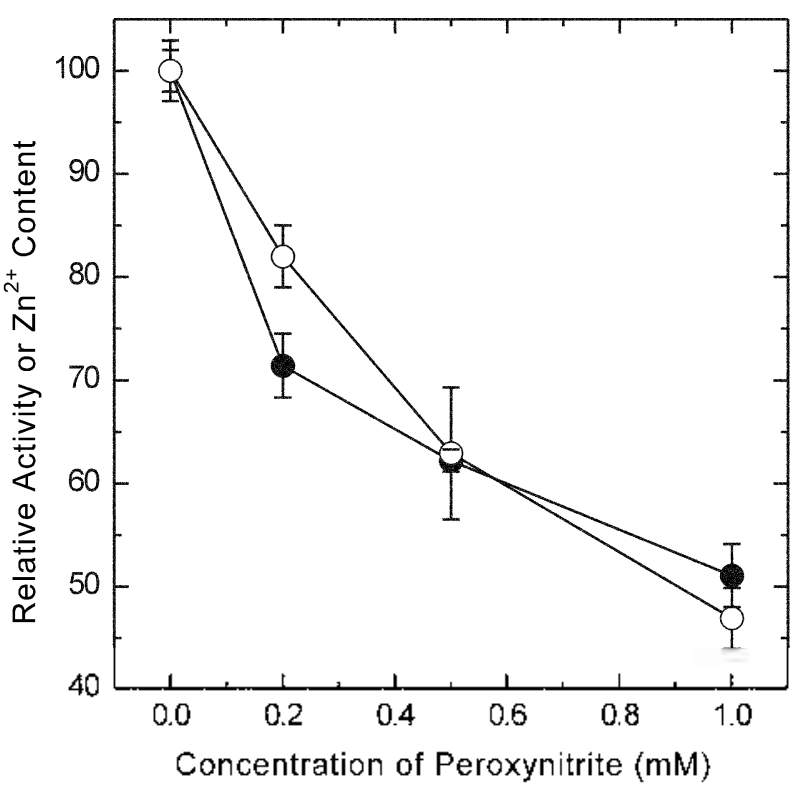

Figure 2. Pcroxynitritc-induced inactivation of carbonic anhydrase II and release of $7 \pi^{2+}$. C.A II $(10 \mu \mathrm{M})$ was incubated will a given concentration of peroxymitrite at $35^{\circ} \mathrm{C}$. for $30 \mathrm{~min}$. The ensyme activity and the concentration of released $\angle \mathrm{n}^{7}$ Here determined according to Experimental Scction.

in $\mathrm{CO}_{2}$ binding and hydration. ${ }^{11}$ We measured the concentration of free $7 \mathrm{n}^{2+}$ in the solution to see if the enzyme inactivation by peroxynitrite was due to the release of $7 \mathrm{nt}^{2-}$. As shown in Figure 2 (open circles), $7 \mathrm{n}^{2+}$ was released proportionally from the enzyme as the peroxynitrite concentration was increased. Other than the slight discrepancy at $200 \mu \mathrm{M}$, the degree of inactivation was well correlated with the loss of $7 \mathrm{n}^{2+}$.

We next employed polyacrylamide gel electrophoresis (PAGS:), under denaturing and non-denaturing conditions, to examine any alterations induced by peroxynitrite in the enzyme structure. The SDS-PAGГ (Fig. 3, upper panel) of the untreated sample exhibited a band at $-30 \mathrm{kD}$. Upon increasing the concentration of peroxynitrite, the intensity of this band did not change and no new bands appeared. This suggests that the peroxynitrite treatment did not result in fragmentation or oligomerization of the protein moiety of CA II.

Unlike SDS-PAGE, there were distinct changes in nondenaturing PAGE as shown in the middle panel of rigure 3 . The untreated sample showed a single band but as the peroxynitrite concentration increased, there appeared additional bands in a ladder-like pattern. It may reflect either the loss of $\mathrm{Zn}^{2-}$ or oxidation of amino acid residues resulting in a net decrease in the positive charge.

Tyrosine and tryptophan residues are major sites of peroxynitrite-induced nitration in proteins. 3-Nitrotyrosine. a reaction product of peroxynitrite and tyrosine, can easily be detected by Westem blotting using antinitrotyrosine antibody. The lower panel of Fig. 3 shows that the concentration of 3-nitrotyrosine increased with the peroxynitrite concentration. The result is not surprising considering that 


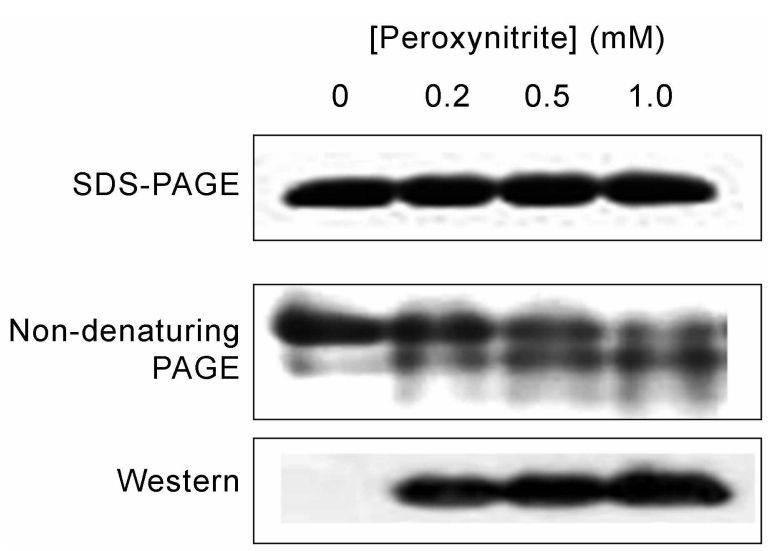

Figure 3. Polyacrylarmide gel electrophoreses and Westem blots of the peroxynitrite-treated carbonic anhydrase II, CA II $(10, \mu \mathrm{M})$ samples treated with given concentrations of peroxynitrite were subjected to $10 \%$ SDS-(upper panel) and $12 \%$ non-denaturing (middle panel) PACiF, and stained with Coumassie hlue. Western blots (lower panel) were oblained by using antinitrotyrosine antibody and LCL reagents.

buman CA II contains seven tyrosine residues.

In order to identify the nitrated residue(s), we digested the samples with trypsin and obtained MALDI-TOF spectra. Nitration should increase the molecular weight by 45 . Unfortunately we were not able to identify a tyrosine residue that was nitrated. Instead, we identified a band at $\mathrm{MW}=2786$ whose intensity decreased with a concomitant increase in the band at $M W=2831$. Searching a data base, we found a matched peptide containing amino acid residues 229-252.

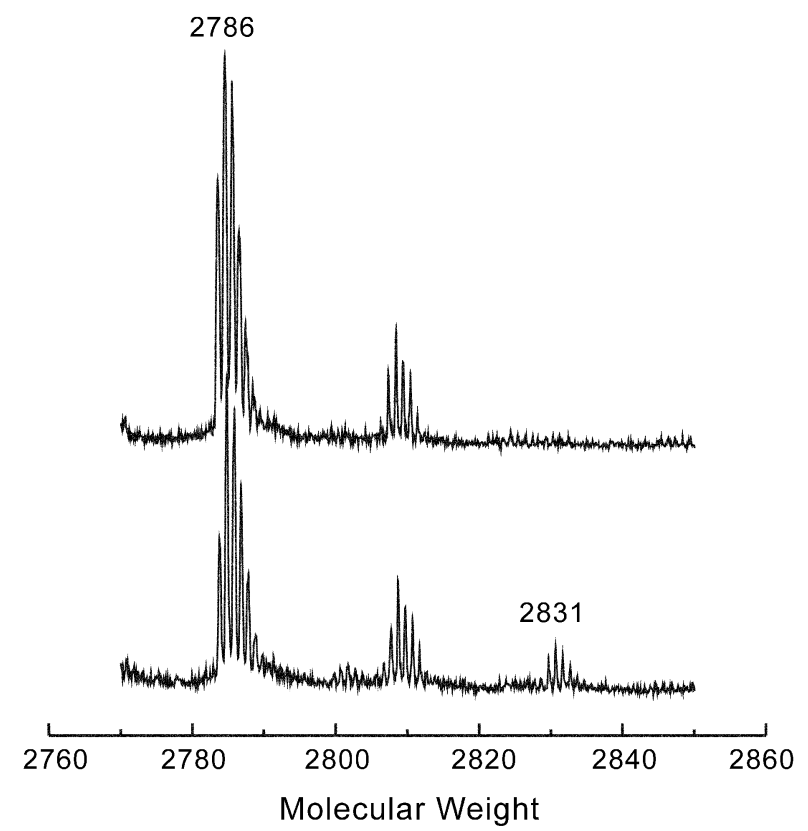

Figure 4. MALDI-IOH mass spectrometry for the identification of nitrated residues. (Intreated (upper) and $1 \mathrm{mM}$ peroxy nitrite-treated (lower) CA II were hydrolyzed by trypsin and their MAL.I)I-TOF: mass spectra were obtained. Note that the intensity of the band at 2786 decreased with a new band appearing at 2831 . The mass dilference of 46 corresponds to nitration.
I.NFNGIGEPECL MVDNWRPAQPI.K. Since this fragment does not contain a tyrosine residue, we suggest that tryptophan- 245 was partially nitrated.

Human CA II has seven tryptophan residues so that it exhibits strong fluorescence when excited at $280 \mathrm{~nm}$. We measured the fluorescence intensity at $350 \mathrm{~nm}$ to estimate modification of tryptophan residues by peroxynitrite. As shown in Figure 5, the tryptophan fluorescence decreased with the concentration of peroxynitrite due to either oxidation or nitration of tryptophan residues. We also measured ANS fluorescence to estimate the exposure of hydrophobic interior of the peroxynitrite-modified CA II. Absence of the increase in the ANS fluorescence intensity indicated that peroxynitrite did not cause a large change in the protein structure (data not shown).

\section{Discussion}

Among the isoforms of carbonic anhydrase, CA III has been studied most extensively for oxidation ${ }^{15}$ and modification $^{16.17}$ by ROS/RNS. Interaction of CA II and ROS/ RNS has not been studied although it binds to band 3 through which superoxide and peroxynitrite enter erythrocytes."

Hydrogen peroxide, hypochlorite, and peroxynitrite represent the major oxidants produced in the blood. We showed that only peroxynitrite inactivated CA II. Hydrogen peroxide normally reacts with redox active transition metals such as $\mathrm{Fe}$ and $\mathrm{Cu}$ to produce extremely strong oxidants. Zine ion in $\mathrm{CA} \mathrm{ll}$ is not redox active so that a direct reaction between $7 \mathrm{n}^{2+}$ and $\mathrm{H}_{2} \mathrm{O}_{2}$ is not likely. Tien if $\mathrm{H}_{2} \mathrm{O}_{2}$ oxidized the single cysteine residue of $\mathrm{CA} \mathrm{I1,} \mathrm{it} \mathrm{is} \mathrm{not} \mathrm{responsible} \mathrm{for} \mathrm{the}$ enzyme inactivation, Interestingly, hypochlorite significantly enhanced the CA Il activity, Since the major targets for hypochlorite are cysteine and methionine, ${ }^{18}$ we again assume that the oxidation of sulfur-containing amino acid residues can not be a cause for the enzyme inactivation.

Peroxynitrite is known to cross-link proteins via dityrosine formation. ${ }^{19}$ It also frequently causes oxidative fragmentation of proteins. ${ }^{20}$ Human CA II has eight tyrosine residues that may be cross-linked when oxidized by peroxynitrite. The SDS-PAGE pattern in Figure 3, however, shows that peroxynitrite caused neither dimerization nor fragmentation of the protein. Instead, non-denaturing PAGE exhibited new bands with lower negative charges. Oxidation of proteins often results in reduction of positive charges as exemplified by oxidized low density lipoprotein." "I the ladder-like pattern we observed, however, may be due to loss of metal ions (i.e. $\mathrm{Zn}^{2+}$ ). A similar phenomenon was observed when Cu. $\mathrm{Zn}$ superoxide dismutase was oxidized by ozone, ${ }^{22}$ singlet oxygen. or peroxynitrite (unpublished data).

3 -Nitrotyrosine is a hallmark of modification of proteins by peroxynitrite." Western blots clearly demonstrated production of 3-nitrotyrosine in peroxynitrite-treated CA II. Efficient nitration of tyrosine residues can be explained by the fact that most of the tyrosine residues in CA II are exposed to the surface of the protein. Quantitation of nitrated 


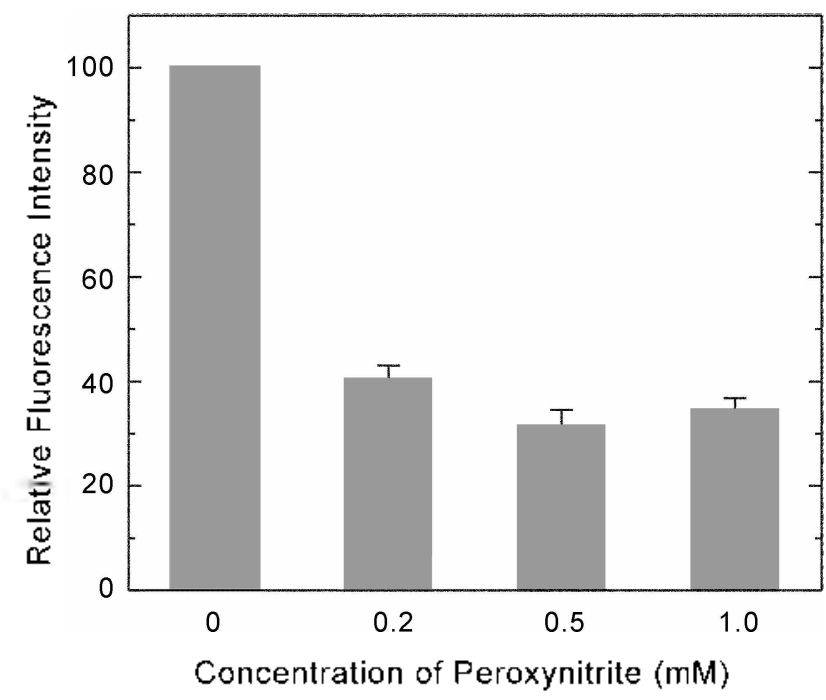

Figure 5. Decrease in tryptophan tluorescence as a function of peroxynitrite concentration. Fluorescence spectra of the samples in liggure 2 were oblained by exciting al $280 \mathrm{~mm}$. The relative fluorescence intensity was measured at $350 \mathrm{~nm}$.

tyrosine by Western blotting is practically impossible so that we were not able to correlate tyrosine nitration with the enzyme inactivation. Attempt to identify the nitrated tyrosine residues was not successful possibly due to a low concentration of nitrated tyrosine. Instead, MAlDDl-TOF mass spectrometry identified tryptophan- 245 as the site of nitration. Tryptophan can be nitrated by peroxynitrite ${ }^{21}$ and by nitrogen dioxide generated by peroxidatic oxidation of nitrite. $^{25}$ The indole ring of trp-245 is completely exposed in the structure of human CA II ( 1 avn,pdb) so that it is prone to attack by peroxynitrite. It is not clear that the nitration of tryptophan is related to the release of $7 . \mathrm{n}^{2+}$.

In summary, we demonstrated that peroxynitrite nitrates tyrosine and tryptophan residues of carbonic anhydrase II without causing fragmentation or dimerization of the protein. The peroxynitrite-induced inactivation of the enzyme is due to the release of the zinc ion in the enzymes active site.

Acknowledgments. This work was supported by Korea
Research Foundation Grant (KRF-2002-015-CP0234).

\section{References}

1. Radi. R.: Polutfo. G.: Alvares. M. N.: Náiliat. M.: Cavota A. Free Radic. Biol. Hed. 2011, 30, 463.

2. Jurkozkan. N.: IJnlu. A.: Ertabak. A.: Cimen. B.: Karabicak. II. (Tin. Chem, lab. Hed. 2001. 30. 1263.

3. Denicola. A.: Souza. J. M.: Radi. R. Proc. Natl. Acad. Sci. ISA 1998. 95.3566 .

4. Nugusto. 0.: I.opes de Menezes, S.: I inares. F.: Romero. V.: Radi. R.: I)enicolit A. Biochentisfry 2002, $41,14323$.

5. Malloczi. C.: Di Stasi. A. M.: Mineti. M. FASFB J. I997. I/. 1281 .

6. Mallozzi. C.: Di Stasi. M. A.: Minctti. M. Hee Radic. Biol Med. 2001. 30. 1108 .

7. Soszonski. M.: Bartos7. G. Biochim. Biophss Acta 1996. 1291. 107.

8. Weiss, S. J. J. Biol. Chem. 1982, 257, 2947.

9. Nagababu. E.: Chrest. F. I.: Rilkind. J. M. Biodnm. Biophiss Acta 2003. 1620.211.

10. Lavodnik. 1. B.: Lapshitı. E. A.: Zavodtik. L. B.: Bartosz. G.: Soszynski. M.: Bryszewska. M. Free Radic. Biol. Hed. 2001. 30. 363.

1]. Tijpp, 13. C.: Smith, K.: Feny. I. (i. J. Biol. Chem. 2001. 276. 48615.

12. Vince. I. W.: Carlsson. U.: Reithmeier. R. A. Biochenistm 2000. 39. 13344 .

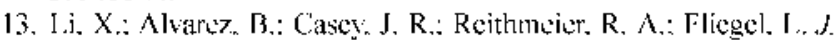
Biot. Chem. 2002, 277, 36085.

14. I!ppu, R. M.: Pryor. W. A. And. Biochem. 1996. 236. 242.

15. Mallis. R. J.: Hamann. M. I.: Zhao. W.: Zhang. 'I.: Hendrich. S.: Thomas. J. A. Biol Chem. 2002. 383.649.

16. Moriguchi. M.: Mastsing. L. R.: Masnning. J. M. Biochem Bionlns. Res. Commm. 1992,183.598.

17. Ji, Y: Akerboom. T. P.: Sics. II.: Thomas, J. A. Areh. Biothem Biophus. 1999. 36?.67.

18. Hawkins. C. L.: Pattison. D. I.: Davies. M. J. Amimo Acids 2003. 25. 259 .

19. Nowak. P.: Wachowicz. B. Platelets 2002. /3. 293.

20. Ischiropoulos. HI.: al-Mahdi, A. B. FEBS Leth. 1995, 36f. 279.

21, Jurgens, Gi.: Hoff, H. F.: Chisolm. G. M., 3rd: Fsterbauler, II. Chen. Phus. Lipids 1987. 45. 315.

22. Lee. Y. K.: Kim. S. M.: Han. S. Biochmie 2003. 85.947.

23. 1schiropoulos. H. Biochem. Biophys. Res. Commm. 2003. 305. 776 .

24. Alvarez. B.: Rubbo. H.: Kirk, M.: Barnes, S.: Freeman. B. A.: Radi. R. Chem. Res. Hoxicol. 1996.9.390.

25. Herold. S. Frec Ratic. Biol. Wed. 20114. 36.565. 